\title{
Length-weight relationship and condition factor of Otolithoides pama (Hamilton, 1822) from Hooghly-Matlah estuarine system of West Bengal, India
}

\author{
DIBAKAR BHAKTA ${ }^{1,2}$, SUDHIR KUMAR DAS ${ }^{1}$, BASANTA KUMAR DAS ${ }^{3}$, T. S. NAGESH ${ }^{1}$, \\ SAMARENDRA BEHERA ${ }^{1}$ AND S. C. S. DAS ${ }^{4}$ \\ ${ }^{1}$ Department of Fisheries Resource Management, Faculty of Fishery Sciences, West Bengal University of Animal \\ and Fishery Sciences, Chakgaria, Kolkata -700 094, West Bengal, India \\ ${ }^{2} I C A R-C e n t r a l$ Inland Fisheries Research Institute, Regional Centre, Vadodara-390 022, Gujarat, India \\ ${ }^{3} I C A R$-Central Inland Fisheries Research Institute, Barrackpore, Monirampur, Kolkata - 700 120, West Bengal, India \\ ${ }^{4}$ ICAR-Central Inland Fisheries Research Institute, 24 Pannalal Road, Allahabad - 211 002, Uttar Pradesh, India \\ e-mail:dibakarbhakta@gmail.com
}

\begin{abstract}
The length-weight relationships (LWRs) of Otolithoides pama (Hamilton, 1822) from the Hooghly-Matlah estuarine system of West Bengal were estimated. The study is based on 618 samples (298 male and 320 female) collected at monthly intervals for a period of 18 months (November 2016 to April 2018) from artisanal catch. No significant difference ( $p>0.01)$ was observed in growth rate for both the sexes. The ' $b$ ' values were estimated at $2.88,2.84$ and 2.86 with ' $\mathrm{r}^{2}$ 'values as 0.96 , 0.95 and 0.95 for male, female and pooled samples respectively. The growth pattern was found to be negatively allometric. The month-wise mean ' $\mathrm{K}$ ' value ranged from $0.70 \pm 0.07$ to $0.78 \pm 0.07$ for male and $0.71 \pm 0.05$ to $0.89 \pm 0.11$ for female. The length-wise estimated mean 'Kn' value varied from 0.92 to 1.17 for male and 0.76 to 1.29 for female indicating the moderately good condition of the fish in the study area. The results can be used for sustainable management and conservation of this commercially important species in this estuary.
\end{abstract}

Keywords: Condition factor, Hooghly-Matlah Estuary, Length-weight relationship, Otolithoides pama

\section{Introduction}

The fishes of the family Sciaenidae, known as drums or croakers due to the sound produced using their swimbladders, are dominant members of continental shelf fauna in tropical and subtropical seas of the Atlantic, Pacific and Indian oceans. Nelson (1994) reported about 270 , mostly marine species in about 70 genera with a few entering freshwaters. Mohanraj et al. (2003) reported that the family Sciaenidae is widely distributed throughout the world with approximately 70 genera and 300 species including about 30 species from Indian waters. Sciaenids are one of the most important commercial fishery resources of India and contributed $30 \%$ of the demersal fish catch during the year 2016-17 (CMFRI, 2016). The total marine fish catch of West Bengal during the year 2015-16 was estimated at 1,73,77 $\mathrm{t}$ and sciaenids contributed $11.45 \%$ (Anon., 2016). Otolithoides pama earlier known as Pama pama (Sciaenoides pama) locally called as 'Bhola' or Poa Bhola forms an important fishery in Hooghly-Matlah estuarine system. They are mainly caught by bag nets and drift gillnets in the Hooghly-Matlah estuarine system.

The knowledge of length-weight relationships (LWRs) has important implications in fishery biology and population dynamics. The length-weight relationship
(LWR) has considerable importance in fishery research especially for the study of fish population dynamics and growth (Mathur and Bhatara, 2007), taxonomic differences, events in life history like metamorphosis, maturity (Le Cren, 1951) and to the fisheries officials in evolving effective policies for management and conservation of the resource. The ratio of the length to the weight is known to be a useful index to indicate the condition of the fish. The LWR in fishes serves many important purposes like estimation of weight from length for individual fish and for length classes of fish, estimations of standing crop biomass when the length frequency distribution is known, to convert growth in length to growth in weight for estimation of weight at age and for use in stock assessment models.

The mathematical relationship between length and weight of fishes is a practical index suitable for understanding their survival, growth, maturity, reproduction and general well-being (Le Cren, 1951) and LWRs are also useful for fishery biologists for monitoring the state of health of a population (Cone, 1989). The asymptotic length $\left(\mathrm{L}_{\infty}\right)$ based on the LWR forms an important parameter for the Beverton and Holt (1956) dynamic pool model.

In general, the expectations are that the weight of the fish is a function of cube $(b=3)$ of the length of fish. 
According to Carlander (1969), the value of ' $b$ ' fluctuates between 2.2 to 4.5, but Pauly and Gayanilo (1997) mentioned that the values may vary from 2.5 to 3.5 . The fishes which follow the cube law in growth i.e., unchanged body form and specific gravity have isometric growth. While fishes which do not follow the cube law in growth rate have allometric growth (positive or negative). The ' $b$ ' values less than 3 indicates that the fish become slender as growth increases and more than 3 indicates fish becomes heavier as size increases (Pauly, 1984). In recent years, several attempts were taken to study the LWRs of finfishes in freshwater and estuarine habitats of West Bengal (Dey et al., 2016; Khongngain et al., 2016; Chakraborty et al., 2017; Pramanick et al., 2017; Sarkar et al., 2017a, b).

The estimation of $\mathrm{K}$ and relative condition factor (Kn) gives information on general well-being of the fish and its development process. In general, the heavier fishes of a given length are in better condition (Bagenal and Tesch, 1978). The condition factor (K) value gives information on the physiological state of the fish in relation to its well-being. The knowledge of fish condition indices provides comparative measures of fish freshness and plumpness. The study of fish condition parameter is a useful, inexpensive and easy measurement tool to know the fecundity, reproduction, growth and mortality rates of fishes (Chakraborty et al., 2017; Pramanick et al., 2017). The condition factor of a fish indicates accumulation of fat in the body and gonadal development (Le Cren, 1951) and also the reproductive status of the fish (Thakur, 1975).

Several researchers have worked on the LWRs and 'K' of sciaenids viz., Rao (1971) on Protonibea diacanthus, Basu (1975) on Otolithes argenteus, Hussain and Abdullah (1977) on six sciaenid fishes from Kuwaiti waters, Murty (1979) and Apparao (1983) on Pennahia macropthalmus and Johnius carutta, Muthiah (1982) on Johnieops vogleri, Murty and Ramalingam (1986) on P. macropthalmus and J. vogleri, Gulati (1987) on Otolithes cuvieri, Kamat (1989) on Johnius glaucus, Mandal et al. (2008) on Johnius gangeticus, Bhuyan (2003) on Otolithes ruber, J. carutta, Kumar et al. (2014) on O. cuvieri, Sandhya et al. (2015) on O. cuvieri and Das et al. (2017) on Nibea maculata.

Nath et al. (2004) were the first to estimate the LWR of P. pama from Hooghly Estuary. Hossain et al. (2015) described the LWRs of Otolithoides biauritus and O. pama from the Tetulia River, southern Bangladesh. Recently Baitha et al. (2018) reported the LWR of O. pama from Ganga River, India. All these studies were based on pooled samples. Hence, the present study was conducted for estimation of LWRs and ' $\mathrm{K}$ ' separately for both male and female of $O$. pama occurring in the Hooghly-Matlah Estuary of West Bengal.

\section{Materials and methods}

The study on the LWR of $O$. pama was based on fish samples comprising both males and females collected from three landing centers namely Godhakhali, Diamond Harbour and Frasergunj under Hooghly-Matlah estuarine system during November 2016 to April 2018. A total of 618 specimens comprising 298 males and 320 females ranging from $100-384 \mathrm{~mm}$ in total length and 7.29-470.71 g in total weight were collected. The freshly collected fish samples were transported to the laboratory in a plastic insulated box after preserving in ice for further studies. At the laboratory, the total length (TL) of the fish specimen was measured from the tip of the anterior-most part of the body to the tip of the caudal fin to the nearest $0.1 \mathrm{~mm}$ using measuring board; weight was noted to the nearest $0.01 \mathrm{~g}$ accuracy using an electronic balance. The LWR for both male and female specimens was calculated separately following the formula (Ricker, 1975): $\mathrm{W}=\mathrm{a} \mathrm{L}{ }^{\mathrm{b}}$. This equation can also be expressed logarithmically as suggested by Le Cren (1951): $\log W=\log a+b \log L$, where $\mathrm{W}=$ weight of fish in $\mathrm{g}, \mathrm{L}=$ length of fish in $\mathrm{mm}$, "a" and "b" are the intercept and regression coefficient respectively, which were estimated using the following formulae:

$$
a=y-b x \text { and } b=\frac{\left[n\left(\sum x y\right)-\sum x \sum y\right]}{\left[n \sum x^{2}-\left(\sum x\right)^{\wedge} 2\right]}
$$

The coefficient of correlation " $r$ " was determined in order to know the relationship between the two variables:

$$
r=\frac{n \sum x y-\sum x \sum y}{\sqrt{\left[\sum x^{2}-\left(\sum x\right)^{\wedge}\right]\left[n \sum y^{2}-\left(\sum y\right)^{\wedge} 2\right]}}
$$

The linear equation was fitted separately for males and females. Analysis of covariance (Snedecor and Cochran, 1967) was used to determine variation in the ' $b$ ' values between the sexes at $5 \%$ level of significance.

Index of well being or condition of fish is measured by condition factor " $\mathrm{K}$ " following Fulton (1902) as: $\mathrm{K}=\frac{\left(\mathrm{W} \times 10^{5}\right)}{\mathrm{L} 3}$, where $\mathrm{K}$ is the condition factor, $\mathrm{W}$ is weight of fish in $\mathrm{g}$ and $\mathrm{L}$ is total length in $\mathrm{mm}$. Condition factor calculated for individual fish was pooled month-wise and sex-wise and the mode in the ' $\mathrm{K}$ ' values can be taken to be an index of gonadal maturity and spawning season or better feeding conditions (Anderson and Gutreuter, 1983).

The relative condition factor can also be used to compare the general well-being, fatness or the state of development of gonad (Froese, 2006). The relative condition factor $(\mathrm{Kn})$ was calculated using the formula: $\mathrm{Kn}=\mathrm{W}_{0} / \mathrm{W}_{\mathrm{c}}$, where $\mathrm{W}_{\mathrm{o}}=$ observed weight and $\mathrm{W}_{\mathrm{c}}=$ calculated weight. Monthly mean values of $\mathrm{Kn}$ 
were calculated for individual samples and the average of the $\mathrm{K}_{\mathrm{n}}$ was estimated accordingly.

\section{Results and discussion}

\section{Length-weight relationships}

The LWR was established for 618 individuals of O. pama within the range of $100-384 \mathrm{~mm}$ in total length and $7.29-470.71 \mathrm{~g}$ total weight. A total of 298 males with the size ranging from $100-327 \mathrm{~mm}(189.59 \pm 27.37 \mathrm{~mm})$ and $7.29-270.00 \mathrm{~g}(53.43 \pm 26.79 \mathrm{~g})$ were used for the study. In females, 320 fishes within the size ranged from $107-384 \mathrm{~mm}$ $(195.65 \pm 38.35 \mathrm{~mm})$ and $10.20-470.71 \mathrm{~g}(65.57 \pm 47.55 \mathrm{~g})$ were used for the study. The LWR for both the sexes is presented through the scatter diagram (Fig. 1) and the logarithmic equation is as follows:

$\begin{array}{ll}\text { Male } & : \log \mathrm{W}=-3.656+2.87581 \log \mathrm{L}\left(\mathrm{r}^{2}=0.956\right) \\ \text { Female } & : \log \mathrm{W}=-3.552+2.83553 \log \mathrm{L}\left(\mathrm{r}^{2}=0.945\right) \\ \text { Pooled } & : \log \mathrm{W}=-3.609+2.85848 \log \mathrm{L}\left(\mathrm{r}^{2}=0.946\right)\end{array}$

The results of LWRs along with the descriptive statistics are presented in Table 1. The logarithmic form of the LWR for both the sexes and pooled samples are presented in Fig. 1.

Generally, the regression coefficient $(b)=3$ for LWR indicates that the fish grows symmetrically or isometrically. Values other than 3 indicate allometric growth (positive or negative allometric). Fish having ' $b$ ' value as 3 maintain their specific body shape throughout their life (Bal and Rao, 1984; Day, 2007). Variation in the relative growth (b) of the species reported from different places suggests an inter-regional difference in the LWR of the fish. Three reports on length-weight of $O$. pama are available, one from Bangladesh and two are from Hooghly Estuary and Ganga River, West Bengal, India.

According to Nath et al. (2004), the ' $b$ ' value for pooled samples of $O$. pama was found to be 3.17, with value of correlation coefficient (r) 0.998 from Hooghly Estuary, which showed a highly significant relationship between length and weight. Hossain et al. (2015) reported LWR of $O$. pama and $O$. biauritus from Tetulia River of Bangladesh and ' $b$ ' values were mentioned as 3.02 $(n=135)$ and $2.55(n=168)$ respectively for combined sexes. For both the species, the LWRs were highly significant $(p<0.01)$ and the coefficient of determination $\left(\mathrm{r}^{2}\right)$ values were 0.954 and 0.974 for $O$. pama and $O$. biauritus respectively. Baitha et al. (2018) reported pooled ' $b$ ' value of 2.86 with ' $r$ ' value as 0.98 from the lower Ganga River of West Bengal.
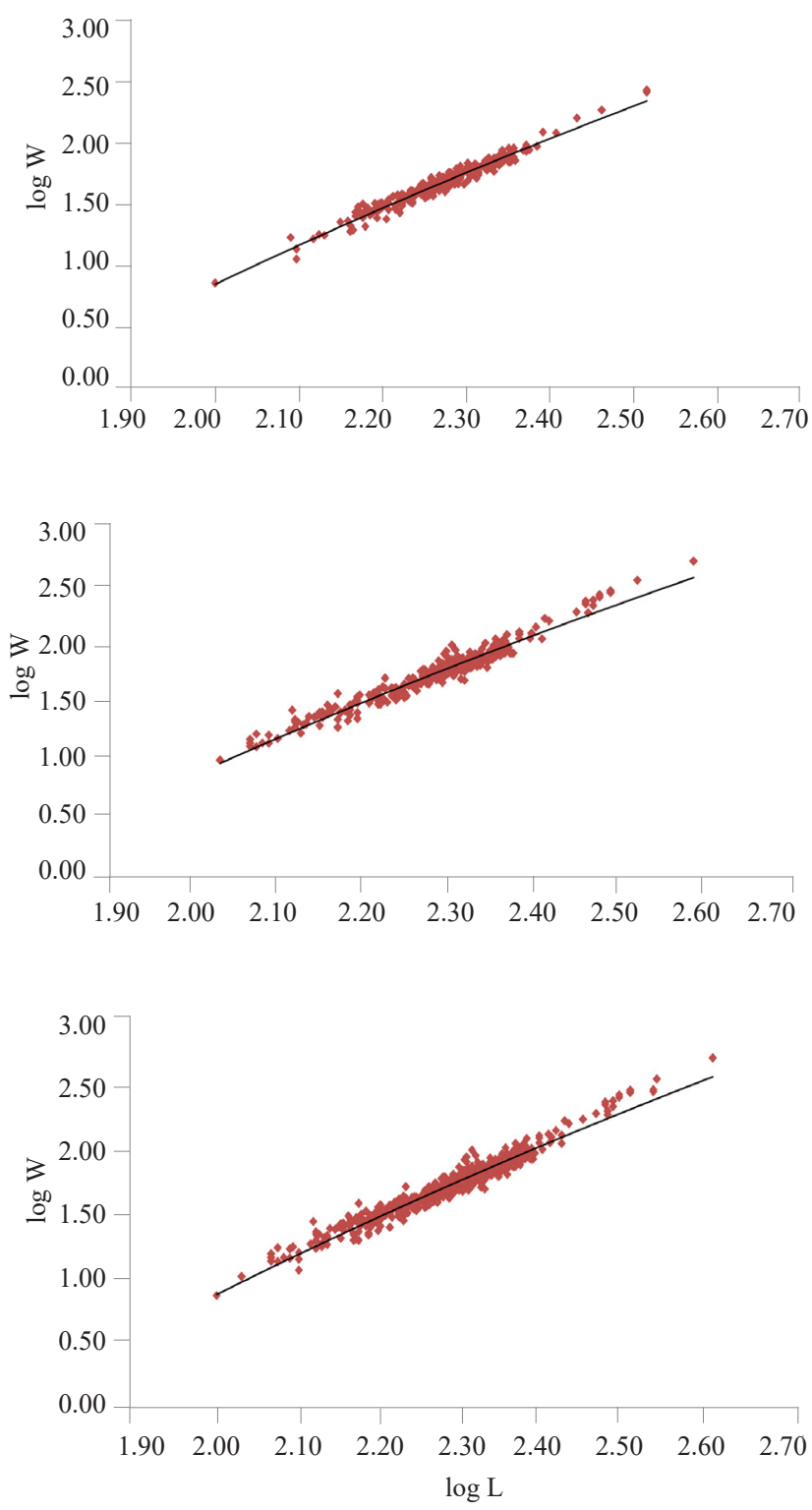

Fig. 1. Logarithmic length-weight relationship of $O$. pama. (a) Male, (b) Female and (c) Sexes pooled

Manojkumar and Acharya (1990) in their study reported ' $b$ ' and ' $r$ ' values as 2.646 and 0.991 for combined sexes of $O$. biauritus collected from Mumbai waters. Ghosh et al. (2009) reported a 'b' value of 2.539 for $O$. biauritus from Diu. The ' $b$ ' value obtained from the present study is similar with the study of Baitha et al. (2018) but differ from Nath et al. (2004) and Hossain et al. (2015). The observed differences in 'b' values may be due to the combination of one or more factors like habitat, area, seasonal effects, the degree of stomach fullness, gonad maturity, sex ratio, health condition, preservation techniques and length groups of studied specimens (Tesch, 1971). A comparative LWR from genus Otolithoides is presented in Table 2. 
Table 1. Descriptive statistics and estimated length-weight distribution of O. pama collected from Hooghly-Matlah Estuary

\begin{tabular}{|c|c|c|c|c|c|c|}
\hline \multirow[t]{2}{*}{ Group } & \multirow[t]{2}{*}{$\mathrm{N}$} & \multicolumn{2}{|c|}{ Regression parameters } & \multirow[t]{2}{*}{$95 \% \mathrm{CL}$ of a } & \multirow[t]{2}{*}{$95 \% \mathrm{CL}$ of $\mathrm{b}$} & \multirow[t]{2}{*}{$\mathrm{R}^{2}$} \\
\hline & & $\mathrm{a}$ & $\mathrm{b}$ & & & \\
\hline Male & 298 & 0.0078 & 2.8758 & $0.0067-0.0091$ & $2.8067-2.9449$ & 0.9577 \\
\hline Female & 320 & 0.0088 & 2.8355 & $0.0074-0.0103$ & $2.7645-2.9066$ & 0.9510 \\
\hline Pooled & 618 & 0.0082 & 2.8585 & $0.0073-0.0092$ & $2.8072-2.9098$ & 0.9510 \\
\hline
\end{tabular}

Table 2. Comparative length-weight relationship of $O$. pama and $O$. biauritus by other researchers

\begin{tabular}{|c|c|c|c|c|c|c|c|c|}
\hline \multirow{2}{*}{$\begin{array}{l}\text { Author } \\
\text { O.pama }\end{array}$} & \multirow[t]{2}{*}{ Sex } & \multicolumn{2}{|c|}{ Intercept (a) } & \multicolumn{2}{|c|}{ Slope (b) } & \multirow[t]{2}{*}{ Correlation coefficient $(r)$} & Sample size & \multirow[t]{2}{*}{ Area of study } \\
\hline & & & & & & & & \\
\hline Nath et al. (2004) & Pooled & \multicolumn{2}{|c|}{0.004071} & \multicolumn{2}{|l|}{3.17} & 0.998 & - & Hooghly Estuary, India \\
\hline Hossain et al. (2015) & Pooled & \multicolumn{2}{|l|}{0.0075} & \multicolumn{2}{|c|}{3.02} & $0.954\left(r^{2}\right)$ & 135 & Tetulia River, Bangladesh \\
\hline Baitha et al. (2018) & Pooled & \multicolumn{2}{|l|}{0.012} & \multicolumn{2}{|c|}{2.86} & 0.98 & 92 & Ganga River, India \\
\hline \multirow[t]{3}{*}{ Present study } & Male & \multicolumn{2}{|c|}{0.0000140} & \multicolumn{2}{|c|}{2.875806} & $0.957742\left(r^{2}\right)$ & 298 & \multirow[t]{3}{*}{ Hooghly-Matlah Estuary } \\
\hline & Female & \multirow{2}{*}{\multicolumn{2}{|c|}{$\begin{array}{l}0.0000183 \\
0.0000158\end{array}$}} & \multicolumn{2}{|c|}{2.835533} & $0.950964\left(\mathrm{r}^{2}\right)$ & 320 & \\
\hline & Combined & & & \multicolumn{2}{|c|}{2.858481} & $0.951047\left(\mathrm{r}^{2}\right)$ & 618 & \\
\hline \multicolumn{9}{|l|}{ O. biauritus } \\
\hline \multicolumn{2}{|l|}{ Hossain et al. (2015) } & Pooled & 0.034 & & 2.55 & $0.974\left(r^{2}\right)$ & 168 & Tetulia River, Bangladesh \\
\hline \multicolumn{2}{|c|}{ Manojkumar and Acharya (1990) } & Pooled & 0.026 & & 2.646 & 0.991 & - & Mumbai waters, India \\
\hline \multicolumn{2}{|l|}{ Ghosh et al. (2009) } & Pooled & 0.154 & & 2.539 & - & - & Diu, India \\
\hline \multirow{3}{*}{\multicolumn{2}{|c|}{ Purushottama et al. (2017) }} & Male & 0.005 & 969 & 3.0 & 0.991 & 289 & North eastern Arabian \\
\hline & & Female & 0.008 & 416 & 2.9 & 0.996 & 273 & Sea, India \\
\hline & & Combined & 0.009 & 158 & 2.9 & 0.994 & 562 & \\
\hline \multicolumn{2}{|l|}{ Kumar et al. (2015) } & Pooled & 1.423 & & 2.539 & 0.758 & 485 & Mumbai waters, India \\
\hline
\end{tabular}

\section{Condition factor $(K)$ and relative condition factor $(K n)$}

The month-wise mean estimated condition factor for both male and female specimens is given in Fig. 2. For the male, the higher monthly mean values of ' $\mathrm{K}$ ' was found during March $(0.78 \pm 0.07)$ and September $(0.78 \pm 0.04)$ and lowest during July $(0.70 \pm 0.07)$ and December $(0.70 \pm 0.05)$. In the case of female, the highest monthly mean ' $\mathrm{K}$ ' values were recorded during March $(0.89 \pm 0.11)$ and lowest during April (0.71 \pm 0.05$)$. For both the sexes, the maximum ' $\mathrm{K}$ ' value was observed during the month of March which is supposed to be one of the peaks of spawning for the fish. For both the sexes there was an irregular trend in ' $\mathrm{K}$ ' values and in most of the months, female specimens were in better condition compared to the males.

The length-wise estimated condition factor for both male and female is given in Fig. 3. For male, length-wise mean ' $\mathrm{K}$ ' values varied from $0.70 \pm 0.06$ to $0.81 \pm 0.00 \mathrm{~mm}$ with lowest in the 220-239 mm length group and the highest in the 260-279 mm length group. For female, the mean lowest value $(0.72 \pm 0.08)$ was recorded from $220-239 \mathrm{~mm}$ length group and highest $(0.90 \pm 0.09,0.90 \pm 0.02$ and 0.90$)$ from 100-119, 300-320 and 320-339 mm length groups respectively. Females were found in better condition in all length groups compared to male specimens. In all the length groups, the ' $\mathrm{K}$ ' values were found to be slightly less

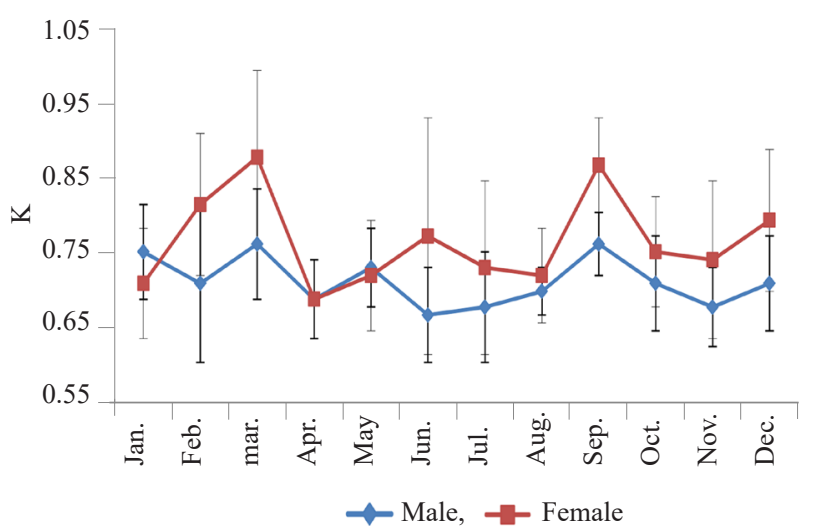

Fig. 2. Month-wise condition factor (K) of $O$. pama

than 1 which indicated that $O$. pama occurring in HooghlyMatlah Estuary were in marginal stressed condition.

In the present study, there was little variation in month-wise 'Kn' values for both the sexes (Fig. 4). For the male specimens, the highest monthly mean 'Kn' values were recorded during the month of February $(1.01 \pm 0.13)$ and for the female during June $(1.03 \pm 0.22)$.

The length-wise estimated ' $\mathrm{Kn}$ ' values are presented in Fig. 5. For male specimens, the highest mean ' $\mathrm{Kn}$ ' value $(1.17 \pm 0.11)$ was observed in the $240-259 \mathrm{~mm}$ length group and lowest $(0.92 \pm 0.00)$ in the $100-119 \mathrm{~mm}$ length group. It was observed that in male specimens, the 


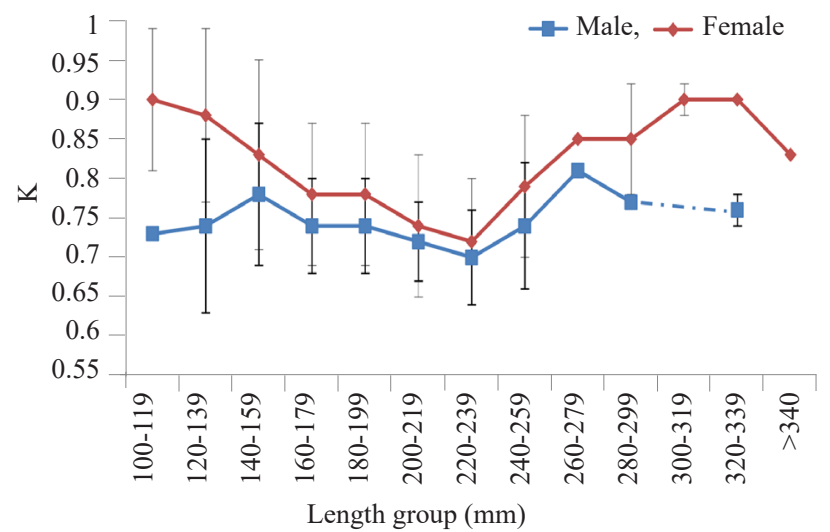

Fig. 3. Length-wise condition factor (K) of O. pama

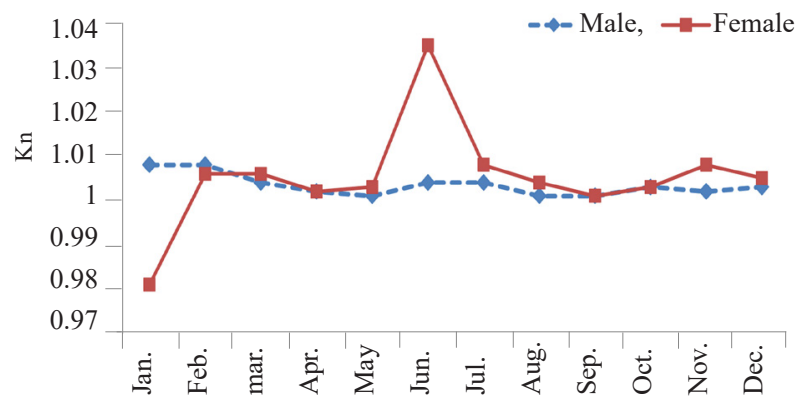

Fig. 4. Month-wise relative condition factor $(\mathrm{Kn})$ of $O$. pama

mean ' $\mathrm{Kn}$ ' values gradually increased from lower length (100-119 mm) group to 220-239 mm length group and highest at 240-259 $\mathrm{mm}$ length group. After that, there was a gradual decline of mean ' $\mathrm{Kn}$ ' values. In the case of female specimens, the lowest mean $\mathrm{Kn}(0.76 \pm 0.15)$ value was noticed in the 140-159 mm length groups and highest $(1.29 \pm 0.00)$ in the $320-339 \mathrm{~mm}$ length group. For females, at initial length groups, the mean ' $\mathrm{Kn}$ ' value was higher and then decreased upto 240-259 mm length group and again it increased in 320-339 mm length group.

The data on length-weight relationships are used for estimating condition factor and these values are used for comparing the general well-being of fishes (Le Cren, 1951; Froese, 2006). The condition factor reflects the physiological state of a fish, which is influenced by both intrinsic (gonadal development, organic reserves, presence or absence of food in the gut) and extrinsic (food availability, environmental variability) factors (Nikolsky, 1969).

In the present study, there was less variation in ' $\mathrm{K}$ ' values for both the sexes and the values were relatively low which may correlate with several factors. For both the sexes, the maximum ' $\mathrm{K}$ ' value was observed during the month of March which is supposed to be one of the peaks of spawning season of the fish. For males, the lowest monthly mean ' $\mathrm{K}$ ' value was observed during July and December and for females during April with females exhibiting better condition than males.

There are many factors which regulate the variation in condition factor in fishes. Hickling and Rutengberg (1936), Thompson (1943) and several other Indian investigators have correlated the lower level of condition with the approach of sexual maturity and spawning in fishes. But Narsimham (1970) mentioned that condition

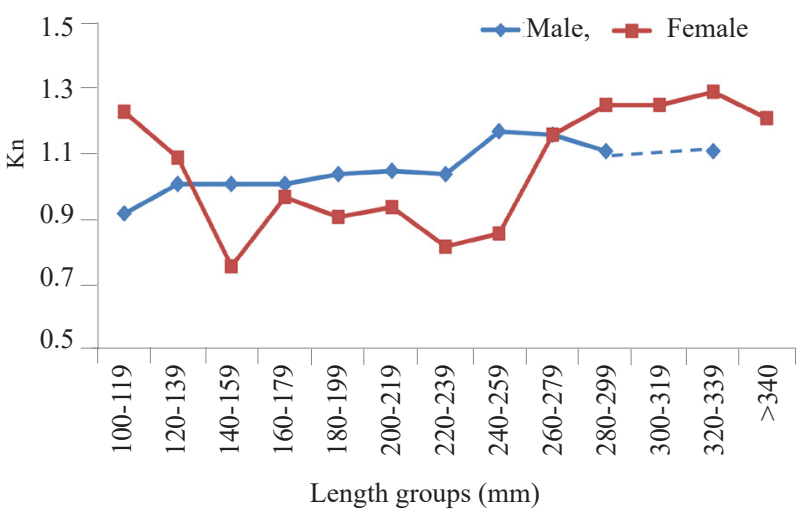

Fig. 5. Length-wise relative condition factor $(\mathrm{Kn})$ of $O$. pama

factor does not necessarily depend on the sexual cycle but is highly related to feeding activity. Significant seasonal and annual differences in condition factors were found for two sciaenids species of Micropogonias furnieri and Cynoscion guatucupa from the Rio de la Plata and Uruguay, south-western Atlantic (Galli and Norbis, 2016). King (1995) mentioned that there are multiple factors which regulate the condition factor in fishes, which include food availability, environmental stress and gonadal development. In the present study, the highest value of condition factors was observed during the spawning season of the species which differs from the other studies related to sciaenids in Indian waters (Nair, 1977; Jayasankar, 1994).

Rangarajan (1971) could not correlate the changes of condition factor either to sexual cycle or intake of food. Baragi and James (1980) reported no difference in the condition of both the sexes of Johnieops osseus from South Kanara coast, but smaller specimens' showed lower condition than larger specimens. As per Baragi and James (1980), maturity and spawning may not be the factors responsible for monthly variation in condition factor in J. osseus. The availability of food items in the environment 
and rate of feeding and several other environmental factors also may be responsible for variation in metabolic activity of the fish which in turn result in raising or lowering the condition during the sexual cycle (Rao, 1963). The variations of ' $\mathrm{K}$ ' in the fish may be indicative of food abundance, adaptation to the environment and gonadal development (King, 1995).

The size of fishes was found to be influential in regulating the condition factor in fishes. Telveker et al. (2006) observed the highest condition factor of O. cuvieri in 300-319 mm length group for female and 240-259 mm length group for male with female specimen showing higher condition compared to male. Month-wise higher ' $\mathrm{K}$ ' value was reported during April and December, which was associated with the breeding periods of the species from Mumbai waters.

Length group-wise condition factor revealed that in lower and higher length groups, the ' $K$ ' values were higher while in middle length groups the values were less which coincides with the study of Sandhya (2012) in O. cuvieri from Ratnagiri waters. Kumar et al. (2014) found the similar trend of monthly ' $\mathrm{K}$ ' values between male and female and parallel trend in different size groups of $J$. carutta from Visakhapatnam coast. The values of ' $\mathrm{K}$ ' showed an increasing trend with an increase in the size of fish except in one or two length groups and the value was influenced by gonadal maturity, spawning season and feeding rate of fish.

There are some studies which reported that the value of condition factor decreased as the size of the fish increased. Hart (1946) also stated that, as the size of the fishes increased, the value of condition factors decreased which is attributed to spawning strains. The highest value of ' $\mathrm{K}$ ' was found in lower length classes, then reduced to medium length classes and again increased in higher length classes of O. cuvieri from Ratnagiri coast (Sandhya, 2012). According to Das et al. (2017), the month-wise 'Kn' values of N. maculata off Gopalpur coast of Odisha varied from 0.8 (April) to 1.18 (February) and in different length class varied from 0.95 to 1.00 . They also mentioned that the ponderal index $(\mathrm{K})$ decreases with increase in length classes. The decrease of ' $\mathrm{K}$ ' value with increase in length classes may be due to higher feeding intensity of smaller fishes compared to the larger fishes which was supported by the work of Das et al. (2017) in N. maculata.

The Kn values could not be correlated with other biological parameters in the present study. Researchers like Baragi and James (1980) also found similar difficulties in correlating the changes in condition factor of the sciaenid $J$. osseus (dussumieri) based on the intake of food and sexual maturity. Rangarajan (1971) also could not correlate these changes either to the sexual cycle or intake of food. Comparative condition factors and relative condition factors of some sciaenids by other researchers are presented in Table 3.

Several other factors like gonadal development and feeding activity also influence 'Kn' values in fishes (Doddamani et al., 2001). Changes in the relative condition factor among seasons for M. furnieri and C. guatucupa could be related to reproduction, feeding habits and/or water temperature (Galli and Norbis, 2016).

The fluctuation in the ponderal index throughout the year can be correlated with sexual maturity cycle and feeding intensity of the species. The results of ' $\mathrm{Kn}$ ' which was found around one, indicates favourable environment for the growth of the fish along Hooghly-Matlah estuarine system.

Table 3. Comparative condition factors and relative condition factors of selected sciaenid speciess by other researchers from the east

\begin{tabular}{lllll}
\multicolumn{1}{c}{ coast of India } & & & \\
\hline Species & Author & Sample size & 'K'/'Kn' & Location \\
\hline Johnius gangeticus & Mandal et al. (2008) & 489 & $1.65-2.05$ & Hooghly-Estuary \\
\hline Johnius carutta & Kumar et al. (2014) & 3406 & $\mathrm{M}=1.290-1.374$ & Visakhapatnam coast \\
\hline Pama pama & & $\mathrm{F}=1.294-1.474$ & \\
& Mitra et al. (2016) & - & 1.009 & Hooghly Estuary \\
Otolithoides biauritus & & - & 0.595 & Matlah Estuary \\
& & & 1.009 & Hooghly Estuary \\
Sciaena biauritus & & 0.918 & Matlah Estuary \\
& & & 1.099 & Hooghly Estuary \\
Nibea maulata & Das et al. (2017) & 680 & 0.992 & Matlah Estuary \\
\hline Otolothoides pama & Present study & 298 & $0.8-1.18(\mathrm{Kn})$ & Gopalpur coast, Odisha \\
& & 320 & $\mathrm{~F}=0.70 \pm 0.05-0.78 \pm 0.07-0.07$ & Hooghly-Matlah Estuary
\end{tabular}




\section{Acknowledgments}

The first author expresses sincere gratitude to the Dean and Head of the Department of Fisheris Resources Management, Faculty of Fishery Sciences, WBUAFS, Kolkata, West Bengal for encouragement and support during research work.

\section{References}

Anderson, R. O. and Gutreuter, S. J. 1983. Length-weight and associated structural indices. In: Nielsen, L. and Johnson, D. (Eds.), Fisheries techniques. American Fisheries Society, Bethesda, Maryland, USA, p. 283-300.

Anon. 2016. Hand book of fisheries statistics 2015-16. Department of Fisheries, The Government of West Bengal, Kolkata, India, 182 pp.

Apparao, T. 1983. Length-weight relationship of Pennahia macrophthalmus (Bleeker) and Johnius carutta (Bloch). Indian J. Fish., 29: 263-266.

Bagenal, T. and Tesch, F. W. 1978. Age and growth, In: Bagenal, T. (Ed.), Methods for assessment of fish production in freshwater, Handbook 3. Blackwell Scientific Publications, Oxford, UK, p. 101-136.

Baitha, R., Karna, S. K. and Ray, A. 2018. Length-weight and length-length relationships of eight fish species from river Ganga, India. J. Appl. Ichthyol., doi.org/10.1111/jai.13698.

Bal, D. V. and Rao, K. V. 1984. Marine fisheries of India, Tata McGraw-Hill Publishing Co. Ltd., New Delhi, p. 243-256.

Baragi, V. M. and James, P. S. B. R. 1980. Reproductive biology of sciaenid fish, Johnieops osseus (Day) from the South Canara coast. Indian J. Mar. Sci., 9: 19-24.

Beverton, R. J. H. and Holt, S. J. 1956. Manual of methods for fish stock assessment.Part 2. Tables of yield function. FAO Fisheries Biology Technical Paper, 38 Rev., 1: 67 pp.

Basu, S. P. 1975. Study on the biology of Otolithes argenteus. M. Sc Thesis, Bombay University, India, 159 pp.

Bhuyan, S. K. 2003. Biology and stock assessment of some sciaenids off Paradeep Coast. Ph. D. thesis. Central Institute of Fisheries Education, 289 pp.

Carlander, K. D. 1969. Handbook of freshwater fishery biology, Vol. I. Life history data on freshwater fishes of the United States and Canada, exclusive of Perciformes. Iowa State University Press, Ames, USA, 752 pp.

Chakraborty, R., Das, S. K. and Bhakta, D. 2017. Length-weight relationship, relative condition factor and food and feeding habits of Channa striata from wetlands of Nadia District, West Bengal. J. Inland Fish. Soc. India, 49(2): 22-26.

CMFRI 2016. Annual Report 2015-16. ICAR-Central Marine Fisheries Research Institute, Kochi, India, 294 pp.

Cone, R. S. 1989.The need to reconsider the use of condition indices in fishery science. Trans. Am. Fish., 118: 510-514.
Das, K. B., Choudhury, D., Das, S. S. and Nanda, S. 2017. Length-weight relationship, relative condition factor and ponderal index of blotched croaker, Nibea maculata off Gopalpur Coast, Odisha. Int. J. Fish. Aquat. Stud., 5(2): 566-570.

Day, F. 2007. The fishes of India (Revised publication). Jagmander Book Agency, New Delhi, India, 186 pp..

Dey, A., Das, S. K. and Bhakta, D. 2016. A comparative study on biological parameters of juveniles and adults of Anabas testudineus (Bloch, 1792) in wetlands of selected districts of West Bengal. Ind. J. Vet. Anim. Sci. Res., 45(5): 793-798.

Doddamani, M., Ramesha, T. J. S. and Shanbhogue S. L. 2001. Length-weight relationship and condition factor of Stolephorus bataviensis from Mangalore area. Indian J. Fish., 48(3): 329-332.

Froese, R. 2006. Cube law, condition factor and weightlength relationships: history, meta-analysis and recommendations. J. Appl. Ichthyol., 22(4): 241-253. doi. org/10.1111/j.1439-0426.2006.00805.x.

Fulton, T. 1902. Rate of growth of sea fishes. Report of scientific investigations, Fisheries Division, Scotland, 20: 326-439.

Galli, O. and Norbis, W. 2016. Length-weight relationships and condition factor of two sciaenid species Micropogonias furnieri and Cynoscion guatucupa from the Rio de la Plata and Uruguayan ocean coast, South-western Atlantic. Revista de Biología Marina y Oceanografia, 51(2): 347-357. DOI 10.4067/S0718-19572016000200012.

Ghosh, S., Mohanraj, G., Asokan, P. K., Dhokia, H. K., Zala, M. S. and Bhint, H. M. 2009.Trophodynamics and reproductive biology of Otolithoides biauritus (Cantor) landed by trawlers at Vanakbara, Diu along the west coast of India. Indian J. Fish., 56(4): 261-265.

Gulati, D. K. 1987. Morphometry, biology and stock assessment of Otolithes cuvieri (Trewavas, 1974) off the Bombay coast. M. Sc. Thesis, University of Bombay, India, 188 pp.

Hart, J. J. 1946. Report on the trawling surveys on the Patagonian continental shelf. Discovery Rep., 23: 223-408.

Hickling, C. F. and Rutenberg, E. 1936. The ovary as an indicator of the spawning period of fishes. J. Mar. Biol. Ass. UK, 311-317.

Hossain, M. Y., Sayed, S. R. M., Rahman, M. M., Ali, M. M., Hossen, M. A., Elgorban, A. M., Ahmed, Z. F. and Ohtomi, J. 2015. Length-weight relationships of nine fish species from the Tetulia River, southern Bangladesh. J. Appl. Ichthyol., 31: 967-969.

Hussain, N. A. and Abdullah, M. A. S. 1977. The lengthweight relationship, spawning season and food habits of six commercial fishes in Kuwaiti waters. Indian J. Fish., 24 (1 \& 2): 181-194.

Jayasankar, P. 1994. Observations on the biology of some sciaenid fishes from Mandapam region. Indian J. Fish., 41(2): 80-86. 
Kamat, S. S. 1989. Stock assessment, dynamics and biology of Johnius glaucus (Day, 1876) resources in the waters off north-west coast of India. M. Sc. Thesis. University of Bombay, India, $92 \mathrm{pp}$.

Khongngain, O., Das, S. K. and Bhakta, D. 2016. Studies of biological parameters of Trichogaster fasciata (Bloch and Schneider, 1801) from a lentic water body Shanti Jheel, West Bengal. J. Indian Fish. Ass., 43(2): 01-06.

King, M. 1995. Fisheries biology, assessment and management. Fishing News Books, Oxford, UK.

Kumar, M. S., Rajeswari, G., Sreeramulu, K. and Kishore, B. 2014. Length-weight relationship and condition factor of karut croaker Johnius carutta, Bloch, 1793 off Visakhapatnam coast. Indian J. Fish., 61(4): 96-98.

Kumar, P., Chakraborty, S. K., Jaiswar, A. K. and Ali, S. 2015. Length-weight relationship and otolith morphometry of twelve species of sciaenids (Family: Sciaenidae) from Mumbai waters, India. Indian J. Fish., 62(2): 104-109.

Le Cren, E. D. 1951. The length-weight relationship and seasonal cycle in gonad weight and condition in the perch (Perca fluviatilis). J. Anim. Ecol., 20: 201-219. DOI: 10.2307/1540.

Mandal, B., Nagesh, T. S., Behera, S. and Devi, O. I. 2008. Length-weight relationship and relative condition factor of Gangetic bola, Johnius gangeticus Talwar from estuarine region of Kakdwip, West Bengal. J. Inland Fish. Soc. India, 40(2): 78-82.

Manojkumar, P. P. and Acharya, P. 1990. Morphometry, lengthweight relationship and food and feeding habits of Otolithoides biauritus (Cantor, 1850) of Bombay waters. J. Indian Fish. Ass., 20: 31-36.

Mathur, N. and Bhatara, M. 2007. Length-weight relationship and relative condition factor $(\mathrm{Kn})$ of Cirrhinus mrigala (Ham.) from two lakes of Ajmer Zone, Rajasthan. Ecol. Env. Cons., 13(2): 225-230.

Mitra, A., Zaman, S., Pramanick, P. and Mitra, S. 2016. Monitoring condition factor of the dominant fin fishes in the estuaries of lower Gangetic Delta in the backdrop of climate change. In: Nautiyal, S., Schaldach, R., Raju, K., Kaechele, H., Pritchard, B. and Rao, K. (Eds.), Climate change challenge (3C) and social-economic-ecological interface-building. Exploring Potential Adaptation Strategies for Bio-resource Conservation and Livelihood Development. Environmental Science and Engineering, Springer International Publishing, Switzerland.

Mohanraj, G., Hameed, B. and Gomathy, S. 2003. Sciaenids. In: Status of exploited marine fishery resources of India. ICAR-Central Marine Fisheires Research Institute, Kochi, p. $133-140$.

Murty, V. S. and Ramalingam, P. 1986. Observations on some aspect of biology of Johnius (Johnieops) vogleri (Bleeker) and Pennahia macrophthalmus (Bleeker) in the Kakinada region. J. Mar. Biol. Ass. India, 28(1and 2): 57-62.

Murty, V. S. 1979. Observation on some aspects of biology of croakers Johnius (Johnieops) dussumieri (Cuvier) and
Johnius (Johnius) carutta Bloch from Kakinada. J. Mar. Biol. Ass. India, 21(1 \& 2): 77-85.

Muthiah, C. 1982. Study on the biology of Johnieops vogleri (Bleeker) of Bombay waters. Indian J. Fish., 29(1 \& 2): 118-133.

Nair, K.V. S. 1977. Maturity and spawning of Johnius (Johnieops) sina (Cuvier) at Calicut during 1969-72. Indian J. Fish., 24(1 and 2): 15-25.

Narsimham, K. A. 1970. On the length-weight relation and relative condition in Trichiurus lepturus. Indian J. Fish., 17(182): 91-96.

Nath, D., Misra, R. N. and Karmakar, H. C. 2004. The Hooghly estuarine system ecological flux, fishery resources and production potential, Bulletin No. 130, ICAR-Central Inland Fisheries Research Institute, Barrackpore, India, $47 \mathrm{pp}$.

Nelson, J. S. 1994. Fishes of the world, $3^{\text {rd }}$ edn. Wiley, New York, USA

Nikolsky, G. V. 1969. Theory of the fish population dynamics as the biological background for rational exploitation and management of fisheries resources. Oliver and Boyd, Edinburgh, UK, 322 pp.

Pauly, D. and Gayanilo. J. F. C. 1997. ABee: An alternative approach to estimating the parameters of a length-weight relationship from length-frequency samples and their bulk weights, International Centre for Living Aquatic Resources Management (ICLARM), Manila, Philippines.

Pauly, D. 1984. Fish population dynamics in tropical waters: A manual for use with programmable calculators. ICLARM Stud. Rev., (8): 325 pp.

Pramanick, S., Das, S. K., Bhakta, D. and Johnson, C. 2017. Length-weight relationship and condition factor of Tade gray mullet, Chelon planiceps (Valenciennes, 1836) from Hooghly-Matlah Estuary, West Bengal, India. J. Fish., 5(1): 469-472. DOI: 10.17017/jfish.v5i1.2017.209.

Purushottama, G. B., Akhilesh, K.V., Chavan, B. B., Katkar, B. N. and Thakurdas Singh, V. V. 2018. Length- weight relationships of ten tropical finfish species from northeastern Arabian Sea, India. J. Appl. Ichthyol., 34:196-199. doi.org/10.1111/jai.13530.

Rangarajan, K. 1971. Maturity and spawning of the Lutjanus kashmira (Forskal) from the Adaman Sea. J. Appl. Ichthyol.,17(1 and2): 114-125.

Rao, K. V. S., 1971. Age and growth of 'Ghol'Pseudosciaena diacanthus (Lacepede) in Bombay and Saurashtra waters. Indian J. Fish., 13: 251-292.

Rao, V. K. 1963. Some aspects of the biology of 'Ghol' Pseudosciaena diacanthus (Lacepede) Indian J. Fish., 10(2): 413-459.

Ricker, W. E., 1975. Computation and interpretation of biological statistics of fish populations. Bull. J. Fish. Res. Board Can., 191: 1-382. 
Sandhya, K. M. 2012. Biology and stock assessment of Otolithes cuvieri (Trewavas, 1974) along Ratnagiri coast. Ph. D. Thesis, ICAR-Central Institute of Fisheries Education, Mumbai, India, 199 pp.

Sandhya, K. M., Chakraborty, S. K., Jaiswar, A. K., Kumar, T. and Mohite, S. 2015. Morphometry and length-weight relationship of Otolithes cuvieri (Trewavas, 1974) from Ratnagiri waters, Maharashtra, north-west coast of India. Indian J. Fish., 62(4): 99-103.

Sarkar, M., Das, S. K., Mondal, A. and Bhakta, D. 2017a. Length-weight relationship and relative condition factor of carps Labeo bata and Labeo rohita from Kulia Beel (wetland) of Nadia District of West Bengal. J. Entomol. Zool. Stud., 5(5): 1033-1036. DOI: 10.3923/jfas.2012.

Sarkar, S., Das, S. K. and Bhakta, D. 2017b. Length-weight relationship and relative condition factor of Indian shad, Tenualosa ilisha from Hooghly estuary system, West Bengal. J. Inland Fish. Soc. India, 49(1): 22-26.
Snedecor, G. W. and Cochran, W. G. 1967. Statistical methods, $6^{\text {th }}$ edn. Oxford and IBH Publishing Co., New Delhi, India. $593 \mathrm{pp}$.

Telvekar, P. A., Chakraborty, S. K. and Jaiswar, A. K. 2006. Length-weight relationship and food and feeding habits of Otolithes cuvieri (Trewavas, 1974) from Mumbai. Indian J. Fish., 53(4): 131-134.

Tesch, W. 1971. Age and growth. In: Methods for assessment of fish production in freshwaters, $2^{\text {nd }}$ edn. Ricker, W. E. (Ed.), International Biological Programme, Oxford and Edinburgh, UK, p. 97-130.

Thakur, N. K. 1975. On the length-weight relationship and relative condition in Clarias batrachus (Linn). Proc. Natl. Acad. Sci., 45(B): 197-201.

Thompson, D. A. W. 1943. On growth and form. University Press, Cambridge, UK, 794 pp. 